\title{
PERSPECTIVE OF FAMILY MEMBERS REGARDING THE PROCESS OF DYING IN THE INTENSIVE CARE UNIT
}

\author{
Thieli Lemos de Souzaㅁ, Sofia Louise Santin Barilli², Nára Selaimem Gaertner de Azeredo ${ }^{3}$
}

\footnotetext{
${ }^{1}$ Specialist nurse in Intensive Care of the Conceição Hospital Group (GHC). Porto Alegre, Rio Grande do Sul, Brazil. E-mail: thieli_20@hotmail.com

${ }^{2}$ M.A. student, Postgraduate Program in Nursing, Universidade Federal do Rio Grande do Sul (UFRGS). Porto Alegre, Rio Grande do Sul, Brazil. E-mail: sofiabarilli@gmail.com

${ }^{3}$ Doctoral student in Children's and Adolescents' Health, on the Postgraduate Program in Medicine, UFRGS. Coordinator of the GHC Adult Intensive Care Unit. Porto Alegre, Rio Grande do Sul, Brazil. E-mail: naras@ghc.com.br
}

\begin{abstract}
This study aimed to investigate the perspective of family members on end-of-life in the Intensive Care Unit. This is an exploratory descriptive study with a qualitative approach. Semi-structured individual interviews were held with eight family members of terminally-ill patients receiving inpatient treatment in an Intensive Care Unit in a public hospital in Porto Alegre, in the State of Rio Grande do Sul . The method of content analysis was used for data analysis. During the process of dying, it was evident that the feelings experienced by the family members were diverse, including distress, insecurity, anger, guilt and missing the loved one. Also demonstrated by the family members were the importance of being with the loved person, and the desire to establish a link between the team-patient-family
\end{abstract}

DESCRIPTORS: Terminally ill. Death. Family. Intensive care units.

\section{PERSPECTIVA DE FAMILIARES SOBRE O PROCESSO DE MORRER EM UNIDADE DE TERAPIA INTENSIVA}

RESUMO: Este estudo objetivou conhecer a perspectiva de familiares sobre a terminalidade da vida na Unidade de Terapia Intensiva. Trata-se de um estudo exploratório descritivo com abordagem qualitativa. Foram realizadas entrevistas individuais semi-estruturadas com oito familiares de pacientes terminais internados em uma Unidade de Terapia Intensiva de um hospital público de Porto Alegre-RS. Para a análise dos dados, foi utilizado o método de análise de conteúdo. Durante o processo de morrer, evidenciou-se que os sentimentos vivenciados pelos familiares foram diversos, como angústia, insegurança, revolta, culpa e saudade. Também foi demonstrado pelos familiares a importância de estar junto da pessoa amada e o desejo de estabelecer um vínculo entre equipe-paciente-família.

DESCRITORES: Doente terminal. Morte. Família. Unidades de terapia intensiva.

\section{PERSPECTIVA DE LA FAMILIA SOBRE EL PROCESO DE MORIR EN UNA UNIDAD DE CUIDADOS INTENSIVOS}

RESUMEN: Este estudio tuvo como objetivo conocer la perspectiva de la familia sobre la terminalidad de la vida en la Unidad de Cuidados Intensivos. Se trata de un enfoque cualitativo exploratorio descriptivo. Se realizaron entrevistas individuales y semiestructuradas con ocho miembros de la familia de los pacientes terminales ingresados en una Unidad de Cuidados Intensivos de un hospital público en Porto Alegre-RS. Para el análisis de datos, se utilizó la técnica de análisis de contenido. Durante el proceso de morir, se hizo evidente que los sentimientos experimentados por los miembros de la familia son diversos, incluyendo ansiedad, inseguridad, ira, culpa y el deseo de estar con la persona. También se demostró la importancia de estar junto a la persona amada y el deseo de establecer un enlace entre equipo de salud-paciente-familia.

DESCRIPTORES: Enfermo terminal. Muerte. Familia. Unidades de cuidados intensivos. 


\section{INTRODUCTION}

Death is the only absolute certainty in the domain of life; it has always existed and always will. However, knowing oneself to be mortal, and facing the finitude of life as something concrete causes fear, disquiet and frustration.

In the past, the process of dying was accompanied by family members, who remained by the side of their loved one, providing them with comfort. Today, the scenario, often, is no longer the same. A significant proportion of deaths occurs in the Intensive Care Unit (ITU), a place specifically for attending seriously-ill patients, who need continuous assistance. This is characterized by a constant expectation of emergency situations, which makes it a stressful environment, for the workers, patients and family members alike. ${ }^{1}$

With time, ITUs have come to receive patients with incurable and terminal illnesses; that is to say, regardless of the therapeutic measures adopted, the disease will inevitably progress to death. The irreversibility of the situation is defined consensually by the medical team, and - once this diagnosis has been established - the principal objectives of the care for the patient are well-being and comfort, allowing a dignified death without suffering. The prioritization of these care measures and the identification of measures which are considered futile must be established by the professional team in agreement with the patient or her representatives. ${ }^{2}$

In addressing terminality, the family's involvement is essential, as this exercises a fundamental role, both in decision-making - when the patient is not able - and in the maintenance of the patient's well-being and comfort, ${ }^{3}$ as their constant presence provides the patient with greater security and tranquility.

When the diagnosis that a disease has progressed beyond therapeutic possibilities is received, the family suffers with the patient and the impact is always very painful. ${ }^{3}$ The situation of tension experienced by the family members can be evidenced frequently by the disorganization of their interpersonal relationships, due to the physical distance from the patient, financial problems and/or fear of losing a beloved entity. ${ }^{1}$

Faced with this scenario, many doubts emerge on the part of family members, principally involving the certainty of the closeness of death. Because of this, the multi-professional team needs to be alert and show itself to be sensitive to the family's needs at this time, seeking effective ways of attending them. ${ }^{1}$

In the practice experienced in the ITUs, it may be observed that the care cannot always be directed towards the anxieties and fears of the patient and her family members, and to the way that these perceive and experience the health-illness process. Due to the often rigid and inflexible routines and norms, the possibility of full participation in the process of terminality is not always offered to the family members as it should be. ${ }^{4}$

In the light of this context, the professional must prepare herself to care for the terminally-ill patient not only in a technical way - so as to meet the technological requirements - but also to extend this activity to the family, promoting care in a way which is responsible and committed, with humanistic values. ${ }^{5-6}$

Coexisting with terminality awoke the desire to reflect on the care for the patient in the final phase of life, and her family. In addition, there is also space for discussing terminality from the perspective of the family members, given that the majority of studies raise considerations related to the multi-professional team responsible for the care for these patients.

A deeper understanding of the aspects involved in terminality instrumentalizes the professionals to develop more qualified care, providing a greater support for those who are experiencing the phenomenon of dying.

\section{OBJECTIVE}

To describe the perspective of the family members of terminally-ill patients regarding the process of dying in ITU.

\section{METHODOLOGICAL TRAJECTORY}

This is an exploratory descriptive study with a qualitative approach, undertaken in the ITU of the Nossa Senhora Conceição Hospital, belonging to the Conceição Hospital Group and located in Porto Alegre in the Brazilian state of Río Grande do Sul (RS). The ITU possesses 59 beds, is of complexity level III and attends adult patients from the public health network.

Interviews were held with eight family members of patients in the final phase of life, receiving inpatient treatment in the ITU. The sampling was determined by saturation. The subjects, over 18 years old, had links of consanguinity or marriage 
and/or affinity with the patient. Prior to the interview, they had been told by the ITU medical team about the final phase of life of their family member. All accepted voluntarily to participate in the study and signed the terms of consent. In order to maintain the interviewees' anonymity, the code F (F1 to F8) was used.

The project was approved by the institution's Research Ethics Committee, under opinion 09-242, on $09 / 01 / 2010$, with ethical aspects of the study involving human beings being respected, in line with that established by Resolution 196/96.

The data were collected through individual semi-structured interviews between September and November 2010, in an environment which assured the subjects' privacy. All the interviews were recorded and transcribed in full, respecting the colloquiality of the discourses.

The data were interpreted using content analysis. ${ }^{7}$ The issues which emerged from the accounts were identified and analyzed with support from the literature and the experience of the authors regarding the study object, with the aim of achieving the investigation proposals.

\section{RESULTS AND DISCUSSION}

The family members interviewed were aged between 30 and 70 years old, most were female (six), and all were married and from Porto Alegre and the metropolitan region. The majority had not finished junior high school. In relation to religious beliefs, six stated that they were Roman Catholics, and two were Spiritualists.

From the analysis of the data obtained, the following categories emerged: the meaning of endof-life in ITU, and the process of dying in ITU for the family members.

\section{The meaning of end-of-life in ITU}

The family's feelings in the process of dying of one of its members are extremely diverse. When the family members become aware of the terminality, they are invaded by a profound pain: [...] It is a pain which you cannot explain... It is the worst time, a pain so horrible that only we can feel it (F4).

Any stress which threatens the person's sense of completeness, inclusion, safety and control can cause anxiety. The admission to ITU, therefore, and the ill person's suffering, tend to shake the family members' and patient's security, causing stress and anxiety. ${ }^{8}$ Hence, the distress also comes through in the accounts of the family members who experienced the suffering of the loved one: there are days when I can no longer stand to see him suffering, I wish that the doctors would say whether they will cure him or not... the doctor said there is no possibility. Why does he need to suffer? (F6).

We also notice that there is great insecurity regarding the possibility of the loss, due to the fact of the death not being expected: [...] I feel completely lost (F4); [...] I didn't expect this so early [...] (F7).

Unexpected situations make people uncomfortable, as they reveal the uncertain and insecure aspect of their lives - which tends to be denied - placing the human being to face her possibility horizon. ${ }^{1}$ As a result, the family members have to experience mourning, confront the fear, overcome the pain and begin again.

In experiencing the closeness of the death of a family member, the person is distressed, not only because of death per se, but mainly due to the baggage of pain and suffering involved in this situation. ${ }^{9}$ The illness can cause a high level of stress in a family nucleus, establishing a crisis. At such a time, some family members experience a phase of anger and, afterwards, of negotiating, which are stages in the development of mourning, ${ }^{10}$ that is, behaviors established for coping with pain, in an attempt to mitigate the suffering and overcome the difficult period: [...] I was very angry... and very sad (F5); I wish I could give a little of my own life, a little bit just for him, for me that would be everything... (F8).

Learning to recognize and accept the reality of the close death is important as much for the person who receives the care as for the health team which provides it. Faced with the fact of the imminent death, the family members, aware of their impotence, end up accepting it: death is certain.... Sooner or later, we have to accept it, because that is how it is [...] (F2); It hurt me deeply, a terrible thing... But there's no way around it, you have to face it because it could be at any moment, I have to accept it, it's hard for us, but we have to accept it (F6).

Guilt is a component which can be experienced in this final stage of life. Frequently, the family members feel themselves to be responsible for the misfortunes which befell their family. These fantasies are caused by the stress experienced. ${ }^{11}$ The feeling of guilt for not having spent more time with the loved one is emphasized: a lot of stuff happened, maybe because I made mistakes, because I didn't know how to deal with the situation I lost a lot of time, I will never recover all that I failed to do with him (F2). 
In waiting for the death, the subjects experience emotions related to the absence of their loved one, such as missing them. In this case, memories have an important role in the development of the mourning and the health professionals can help in this, facilitating rituals and promoting memories. ${ }^{12}$ The family members describe moments experienced and emphasize the relevance of the loved one in their lives: I think I am already missing him, you know, there are all those times which we spent together (F1); [...] but the feeling of missing him, the memories remain $[. .].(\mathrm{F} 4)$.

During the process of dying, religious values appear as closely related to the aspects of the care in situations of human suffering. ${ }^{13}$ In this regard, the religious and spiritual beliefs are mechanisms, accessed in order to mitigate the feelings which permeate this period.

Studies show that $95 \%$ of Americans believe in some higher force ${ }^{14-15}$ and that $93 \%$ would like their doctors to address these questions if they were to become seriously ill. ${ }^{16-17}$ Patients receiving inpatient treatment (77\%) wish their spiritual values to be taken into account by the doctors, and $40 \%$ would also like their doctors to pray with them. The majority of the patients, however, say that their doctors never address this issue. ${ }^{18}$

Spirituality is a human characteristic which allows the individual to find meaning and purpose for life. The situations which precede and involve the process of death and dying are among those in which spirituality and the need for spiritual comfort are most evident: ${ }^{13}[. .$.$] I believe that it is$ the hand of God over that person (F4); if there is no chance, may God take him, but don't make him suffer, you know, I am weary, I don't want to see him like this anymore $[. .].(\mathrm{F} 8)$.

In coming face-to-face with the death of a loved one, the individual comes to perceive life differently, identifying it as something fragile, ephemeral and perishable - and rethinks values and beliefs. ${ }^{9}$ In experiencing this process, some people comfort themselves in undertaking religious rites, adding peace and calmness to the environment of grief: [...] the priest came, marvelous, an excellent person, mom already became calmer (F1).

The relevance of faith and hope as mechanisms of multidimensional understanding of the human being become essential for understanding the process which surrounds health and illness and the healthy coping with all its specific characteristics. ${ }^{13}$ Manifestations of faith at this time are common; they represent a way of finding strength to carry on: [...] I have faith that he, I don't know, something will happen, I believe in miracles, what if there is a miracle... The doctor said: 'there is nothing more we can do'. But if God wills it, it is God who will do it (F8).

In daily life, death is characterized as a distant possibility, and due to this perspective, security in the future and in realizing dreams is preserved; but a simple premonition of its arrival kindles feelings of agony in the human being. ${ }^{9}$ The family members who passed through this period need to elaborate the possibility and, sometimes, the concretization of the loss of their family member, so as to follow the normal course of their lives.

\section{The process of dying in ITU for the family members}

Until not long ago, people faced death at home, beside their family and friends. Currently, the hospital is the new place for death and changes the meaning of dying. In general, people die alone, in the solitude of a hospital bed. ${ }^{19}$

The majority of intra-hospital deaths occur in ITU, where the participation of the family is very restricted, as it is limited to visiting hours. Generally it is at this time that the family member is informed about the terminality of the life of their loved one: at visiting time, the doctor broke it to us gently. As I understood it, I thought it was the end of his life. Today it was confirmed that his kidneys stopped, that his lungs stopped (F4).

In ITU, the main person who provides this communication about the patient is the doctor, who must provide clear and realist, yet compassionate and sympathetic, information. It is fundamental to speak about the real prognosis and to clearly inform one's listeners about the progression of the disease, without forgetting the emotional involvement which surrounds dying. ${ }^{20}$

At the same time as the communication takes on the role of being an instrument of care in the process of dying, communicating bad news is one of the more difficult tasks undertaken by the health professional, perhaps because in academia they learned to save lives rather than deal with situations of loss of health, vitality and hope, and death.

Whether it is information requested by the family members, or an essential feature of the interpersonal relationship, empathetic communication is an instrument which provides support in the face of the terminality. Because of this, it is not merely a matter of transmitting information, 
but rather of how the information is transmitted: the doctor during the week was more delicate, cautious when speaking with us. The one at the weekend was like this: 'He's going to die, I just wanted to tell you that the patient is going to die' (F8).

In addition, the end-of-life of a terminallyill patient is fertile ground for questions: I have doubts regarding when they are going to turn off the equipment... When is the last thread of his life? Is he in a coma or is he just sedated? (F4); [...] is it the machine which is breathing for him? (F6).

At the end of life, the meetings can be complex when there is no prior relationship between the health professionals and family members. It would be ideal if the person responsible for providing the news were always the same and, in addition, had experience - both technical and ethical. It is necessary to understand that, when the family members are informed about the closeness of their loved one's death, they generally experience many feelings: a combination of shock, uncertainty, sadness, confusion, stress, anxiety and unease. ${ }^{21}$ It falls to the professional to adopt an embracing stance and develop communication skills, as it is through this that the family member develops trust and feelings of security.

The form of communication influences the satisfaction with the services provided. The majority of the relatives of critically-ill patients consider appropriate communication, correct decision-making, respect and compassion for the patient and her family members as determinants for the family's satisfaction: ${ }^{21}[\ldots]$ being available to explain things to you, to listen to you, to answer you, I'm very content (F5); [...] I was the person who spoke most with the doctors; just the fact of them providing me with advice made me feel welcomed (F7).

A search for support and confidence, both through the care provided and from differentiated attention when providing information to family members, is extremely relevant in the relationship established between the team-family-patient. ${ }^{22}$ Effective and affective communication minimizes difficulties and uncertainties and strengthens the feeling of security, facilitating the good relationship, which is vital for the quality of the care: the doctor spoke with me, the nurse did too... They said that they weren't going to do any more tests, that they would try to ventilate him, medicate him, so there would be no pain, for the calmest end possible [...] (F6).
One study undertaken in Brazil, ${ }^{23}$ which used the Critical Care Family Needs Inventory, identified information as one of the priority aspects in the family members' needs. It is through the information given by the multi-professional team that those responsible for the patient become aware of the clinical situation and, in this way, feel safe to take decisions.

It is a daily challenge to deal with the worsening state of the patient who is beyond cure, but for whom care is still possible. ${ }^{22}$ Often, the hope is not for life, but for a dignified death: I wish his suffering would stop (F3); [...] what concerns me most is his well-being... that he should not feel pain (F4).

It is fundamental, not only - but mainly - in ITU, to understand the family as an extension of the patient. The family members need to understand the process of dying, minimizing their distress and concern with the pain associated with death. ${ }^{22}$ As a result, the health team has the duty to afford the patient a dignified death and assure to the family a humanized process.

In the context of end-of-life care, the family members generally feel frustrated and guilty for not being with their loved one. For them, being at the side of whom they love is the main way of participating in this unique moment: [...] touching her gently, even if it's just a little, even if she can't feel anything... It is saying goodbye, I think this is important, being able to be there (F1); I talk about when we were little, things that we used to do, and my mom and my dad were alive... I think he can hear me, because he was looking at me and was listening to me (F2); [...] I lost a lot of time, I spent more than five years without seeing him, so, for me, every little bit of time that I spend here, for me feels like an hour [...] (F8).

It is known that the dynamic of the ITU does not generally allow the family member to be present at the moment of death. Perhaps due to this, dying is unbearably sad in various ways: solitary, mechanical, and dehumanized; dying becomes an impersonal act. ${ }^{10}$ For the family, the fact of the patient experiencing it without being with whom she loves is particularly distressing: [...] She's going to be alone, the poor thing, wondering if she's going to die here, with nobody from the family with her (F1); he can't go to his room for us to be together for him to disincarnate, * because of the ventilator, perhaps he will have to disincarnate here (F5).

* Disincarnate: Spiritualist term, meaning to die. Translator's note. 
The presence of the family in the process of death and dying is not only an act of solidarity, but also a scientifically-based strategy. There is evidence that the patients who have their loved ones around them in this phase need less sedation and analgesia. ${ }^{24}$

One must ensure that the inclusion of family members in the process of end-of-life occurs in a context of participation, considering their role as fundamental. When the patient understands the arrival of death and shares this with the family and the team, the feelings of solitude and defeat diminish, being replaced by tranquility.

\section{FINAL CONSIDERATIONS}

The process of dying in ITU is still littleunderstood by the families, giving rise to an environment which is favorable to the appearance of doubts, which must be resolved by the multi-professional team, if they are to be replaced by feelings of security, minimizing the anxiety. The afore-mentioned perspective leads the family members to think of ITU as a "place to die" alone, in suffering, and sad.

Although death will always be a difficult issue, failing to think about it neither delays nor avoids it. This being the case, reflection helps its acceptance and the perception that it is an experience as important as any other, although painful.

As was seen in this study, spirituality is shown to be relevant in coping with the process of the end of life, as it allows the acceptance of the family members' pain and suffering. Furthermore, communication is another relevant aspect for mitigating the distress, and is characterized as a trigger for the family's satisfaction with the care provided by the multi-professional team.

The family members interviewed considered it to be important to spend more time with the loved one; they are distressed at knowing that death could be alone; they recover the importance of tenderness, of memories, of being by the person's side, and of saying goodbye. In the same way, the subjects emphasize the need for the relief of the patient's pain, and the longing for the patient to have a dignified death with less suffering appears in the accounts. It is evident that the fear is not of death, but rather of the process of dying.

The ITUs and the professionals who work there, however, remain unprepared to assist the families with the patients. Perhaps this context should also be the responsibility of the academic training of the courses in the area of health, which little address such relevant themes as: the process of dying, family, and palliative care. It is fundamental for the students and professionals to approach issues, not in a marginal way, but as knowledgeable and compassionate protagonists.

The aim is that this study should be a trigger such that new practices in relation to the family members should become a reality within ITU or, at least, that their inclusion in intensive care should be discussed. In talking of change, the idea is to integrate the patients' families in the care and in the discussion, always respecting their fears, distress, and limits.

It is time to understand the care as an opportunity for learning based on exchange, sensitivity, and on the conscious intention to be with the other. Understanding the process of dying, and its meanings for the family members, provides important elements for comprehensive, humanized and embracing care, respecting the individual's autonomy, and ensuring her a dignified death.

\section{REFERENCES}

1. Urizzi F, Carvalho LM, Zampa HB, Ferreira GL, Grion CML, Cardoso LTQ. Vivência de familiares internados em unidades de terapia intensiva. Rev Bras Ter Intensiva. 2008; 20(4):370-5.

2. Moritz RD, Lago PM, Souza RP, Silva NB, Meneses FA, Othero JCB, et al. Terminalidade e cuidados paliativos na unidade de terapia intensiva. Rev Bras Ter Intensiva. 2008; 20(4):422-8.

3. Ferreira NMLA, Souza CLB, Stuchi Z. Cuidados paliativos e família. Rev Ciênc Méd. 2008; 17(1):3342.

4. Moritz RD, organizador. Cuidados paliativos nas unidades de terapia intensiva. São Paulo (SP): Atheneu; 2012.

5. Silva CF, Souza DM, Pedreira LC, Santos MR, Faustino TN. Concepções da equipe multiprofissional sobre a implementação dos cuidados paliativos na unidade de terapia intensiva. Ciênc Saúde Colet. 2013; 18(9):2597-604.

6. Komessu JH. Assistir familiares de pacientes fora de possibilidades terapêuticas: competência do enfermeiro [tese]. São Paulo (SP): Universidade de São Paulo; 2009.

7. Bardin L. Análise de conteúdo. $6^{\mathrm{a}}$ ed. Lisboa (PT): Edições 70; 2012.

8. Bizek KS. A experiência do paciente com doença crítica. In: Morton, PG. Cuidados críticos de enfermagem: uma abordagem holística. 9a ed. Rio de Janeiro (RJ): Guanabara Koogan; 2011. p.12-36. 
9. Santos EM, Sales CA. Familiares enlutados: compreensão fenomenológica existencial de suas vivências. Texto Contexto Enferm. 2011; 20(esp):21422.

10. Kübler-Ross E. Sobre a morte e o morrer. $9^{\text {a }}$ ed. São Paulo (SP): Martins Fontes; 2008.

11. Cassorla RMS. Negação e outras defesas frente à morte. In: Santos FS, organizador. Cuidados paliativos: discutindo a vida, a morte e o morrer. São Paulo (SP): Atheneu; 2009. p.59-76.

12. Souza JL, Costa SMM, Salcedo EAC, Camy LFS, Carvalho FL, Duarte CAM, et al. A família, a morte e a equipe: acolhimento no cuidado com a criança. In: Santos FS, organizador. Cuidados paliativos: discutindo a vida, a morte e o morrer. São Paulo (SP): Atheneu; 2009.p.145-64.

13. Penha RM, Silva MJP. Significado de espiritualidade para a enfermagem em cuidados intesivos. Texto Contexto Enferm. 2012; 21(2):260-8.

14. Hinshaw DB. Spiritual issues in surgical palliative care. Surg Clin North America. 2005; 85(2):257-72.

15. Spirituality in Cancer Care [Internet]. Bethesda (MD): National Cancer Institute (US); 2010 [acesso 2010 Jul 10]. Disponível em: http://cancer.gov/ cancertopics/pdq/supportivecare/spirituality/ HealthProfessional

16. Ehman J, Ott BB, Short TH, Ciampa RC, HansenFlaschen J. Do patients want physicians to inquire about their spiritual or religious beliefs if they become gravely ill? Arch Intern Med. 1999; 159(15):1803-6.

17. Steinhauser KE, Voils CI, Clipp EC, Bosworth HB, Christakis NA, Tulsky JA. "Are you at peace?": one item to probe spiritual concerns at the end of life. Arch Intern Med. 2006; 166(1):101-5.

18. King D, Bushwick B. Beliefs and attitudes of hospital inpatients about faith healing and prayer. J Fam Pract. 1994; 39(4):349-52.

19. Ariés P. História da morte no ocidente. São Paulo (SP): Saraiva de Bolso, 2012.

20. Wallau RA, Guimarães HP, Falcão LFR, Lopes RD, Leal PHR, Senna APR, et al. Qualidade e humanização do atendimento em Medicina Intensiva. Qual a visão dos familiares? Rev Bras Ter Intensiva. 2006; 18(1):45-51.

21. Heyland DK, Rocker GM, O'Callaghan CJ, Dodek PM, Cook DJ. Dying in the ICU: perspectives of family members. Chest. 2003; 124(1):392-7.

22. Silva RS, Campos AER, Pereira A. Cuidando do paciente no processo de morte na unidade de terapia intensiva. Rev Esc Enferm USP. 2011; 45(3):738-44.

23. Freitas KS, Kimura M, Ferreira KASL. Family members' needs at intensive care units: comparative analysis between a public and a private hospital. Rev Latino-Am Enferm. 2007; 15(1):84-92.

24. Fridh I, Forsberg A, Bergbom I. Family presence and environmental factors at the time of a patient's death in an ICU. Acta Anaesthesiol Scand. 2007; 51(4):395-401. 